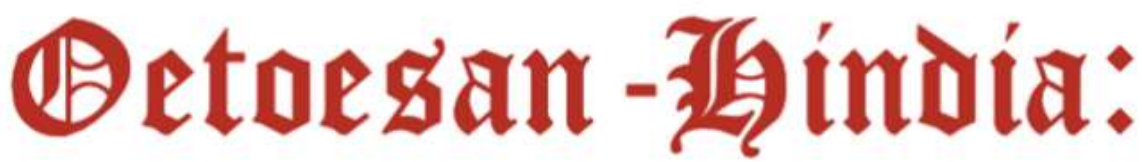 \\ Telaah Pemikiran Kebangsaan
}

Volume 2 No 1 Tahun 2020 Hlmn. 1-14

Artikel Masuk: 15 November 2019 | Artikel Diterima: 31 Juli 2020

\section{Kepemimpinan islami dalam manajemen lembaga pendidikan}

\author{
Iskandar Eka Asmuni
}

Yayasan Rumah Peneleh, Pondok Indah Estate Blok B No 11A, Malang, Indonesia, 65124

iskandar.ekaasmuni96@gmail.com

*surel korespondensi: iskandar.ekaasmuni96@gmail.com

\begin{abstract}
Abstrak
Penelitian bertujuan untuk menelaah sejauh mana peran pemimpin dan penerapan kepemimpinan Islami pada lembaga pendidikan Islam. Lembaga yang berlandaskan Islam haruslah menjadikan Al-Quran dan Hadist sebagai pijakan dasar dalam setiap Manajemen, tak luput juga dalam hal Kepemimpinan, dalam hal ini dipotret melalui sifat-sifat Kenabian, yaitu Sidiq, Amanah, Tabligh dan Fatonah. Metode yang digunakan adalah metode penelitian kualitatif dengan pendekatan studi kasus. Hasil penelitian menujukkan secara garis besar bahwa nilai-nilai Islam sudah diterapkan dan selalu dipertahankan dalam proses kepemimpinan. Nilai kepemimpinan islami seperti siddiq, amanah, tabligh dan fatonah sudah diterapkan pada perannya sebagai pemimpin yaitu sebagai panutan, perintis, penyelaras dan pemberdaya.
\end{abstract}

Kata Kunci: Peran Pemimpin; Kepemimpinan islami; Sifat Kenabian

\begin{abstract}
This study aims to examine the extent of the Role of Leaders and the Application of Islamic Leadership in Islamic educational institutions. Institutions that are based on Islam must make the Quran and Hadiths as a basic foothold in every management, not least in terms of leadership. In this case it will be portrayed through the attributes of Prophethood, namely Sidiq, Amanah, Tabligh, and Fatonah. The method used is a qualitative research method with a case study approach. The results of the study show in broad outline that Islamic values have been applied and are always maintained in the leadership process. The values of Islamic leadership such as siddiq, amanah, tabligh, and fatonah have been applied to their role as leaders, namely as role models, pioneers, harmonizers, and empowerers.
\end{abstract}

Keywords: Role of Leaders; Islamic Leadership; Prophetic Nature

Kepemimpinan islami memengang teguh prinsip bahwa dunia merupakan jalan menanam benih-benih kebaikan yang kemudian akan di panen di akhirat. Dunia hanya perjalanan sementara yang semuanya 


\section{Kepemimpinan islami dalam .... Asmuni, I.E.}

bermuara di akhirat. Prinsip kepemimpinan islami ini menempatkan Allah dan Rosulullah sebagai pusat dari dirinya menampakkah wajah di muka bumi. Lebih dari itu, Adiba (2018) menjelaskan bahwa kepemimpinan islami harus mampu mengarahkan, melindungi dan memperlakukan sesuatu seadiladilnya.

Seorang pemimpin islami harus bisa menjadi tokoh sentral dalam menciptakan kepribadian yang baik di antara lingkungan sekitarnya. Termasuk dalam dunia pendidikan, sebagai suri tauladan kepada muridmuridnya. Sebab, pendidikan salah satu gerakan dakwah penyadaran dalam membimbing dan membina peserta didik melalui bimbingan, pengajaran dan latihan sebagai generasi dimasa datang (Suwardi dan Samino, 2014). Pada realitasnya, pendidikan dalam pelaksanaannya mulai menghadapi perubahan sosial akibat perkembangan teknologi dan informasi. Pendidikan tidak lagi berorientasi kepada perbaikan akhlak, tetapi lebih kepada eksistensi dan kebutuhan tenaga kerja. Oleh karena itu, pendidikan diharapkan ke depannya menjadi proses transfer nilai, membentuk pribadi yang luhur budi pekertinya, serta mampu bermanfaat kepada kepentingan umat manusia. Sebagaimana amanah Sistem Pendidikan Nasioanal pasal 3 dalam UU No.20 tahun 2003 menyebutkan bahwa sekolah harus bisa mengembangkan potensi peserta didik agar menjadi manusia yang beriman dan bertaqwa kepada Tuhan yang Maha Esa, berakhlaq mulia, sehat, berilmu, cakap, kreatif, mandiri, dan menjadi warga Negara yang demokratis serta bertanggung jawab.

Salah satu lumbung yang berusaha untuk menerapkan apa yang tertuang di dalam kitab suci maupun undang-undang adalah Lembaga pendidikan "Yayasan Bani Hasyim" yang terletak di Singosari - Malang. Sebagai lembaga yang berlandaskan pada Agama Islam dan prinsip lokalitas kebudayaan serta sudah bertaraf Internasional, Bani Hasyim tentunya membutuhkan kemampuan manajerial yang baik guna mencapai tujuan lembaga, termasuk praktik kepemimpinan. Para jajaran pemimpin memimipin organisasi atau lembaga yang berbasis islami, maka nilai-nilai islami seharusnya juga diterapkan dalam aktivitas memimpinnya, sehingga tujuan utamanya dapat tercapai yakni mencerdaskan kehidupan bangsa sebagai bentuk beribadah kepada Allah SWT (Subhan, 2013). Penelitian ini berbeda dengan penelitian terdahulu yang membahas tentang kepemimpinan Islami hanya dari konsepnya saja, misalnya Subhan (2013), Husna (2017), Muzammil (2017), dan Ikhwan (2018) untuk sekolah, sedangkan Shalihah (2015) membahas konsep kepemimpinan Islami di perusahaan.

Begitu pentingnya peranan kepemimpinan Direktur Pendidikan Yayasan dan kepala sekolah dalam proses pencapaian tujuan pendidikan, maka peneliti mencoba menelaah sejauh mana peran dan penerapan kepemimpinan islami dalam mengelola lembaga pendidikan ini. 


\section{METODE}

Penelitian ini menggunakan metode kualitatif dengan pendekatan studi kasus. Objek penelitian adalah lembaga pendidikan Bani Hasyim yang terletak di Singosari-Malang. Pengambilan data dengan cara wawancara dan pengamatan yang dilakukan sekitar tiga minggu kepada 10 informan, yaitu Direktur pendidikan yayasan, kepala sekolah, guru dan wali murid dari masing-masing jenjang mulai dari KB-TK, SD dan SMP. Penentuan informan menggunakan metode 5R (Relevance, Recommended, Rapport, Readinness, reassurance) (Kamayanti, 2016).

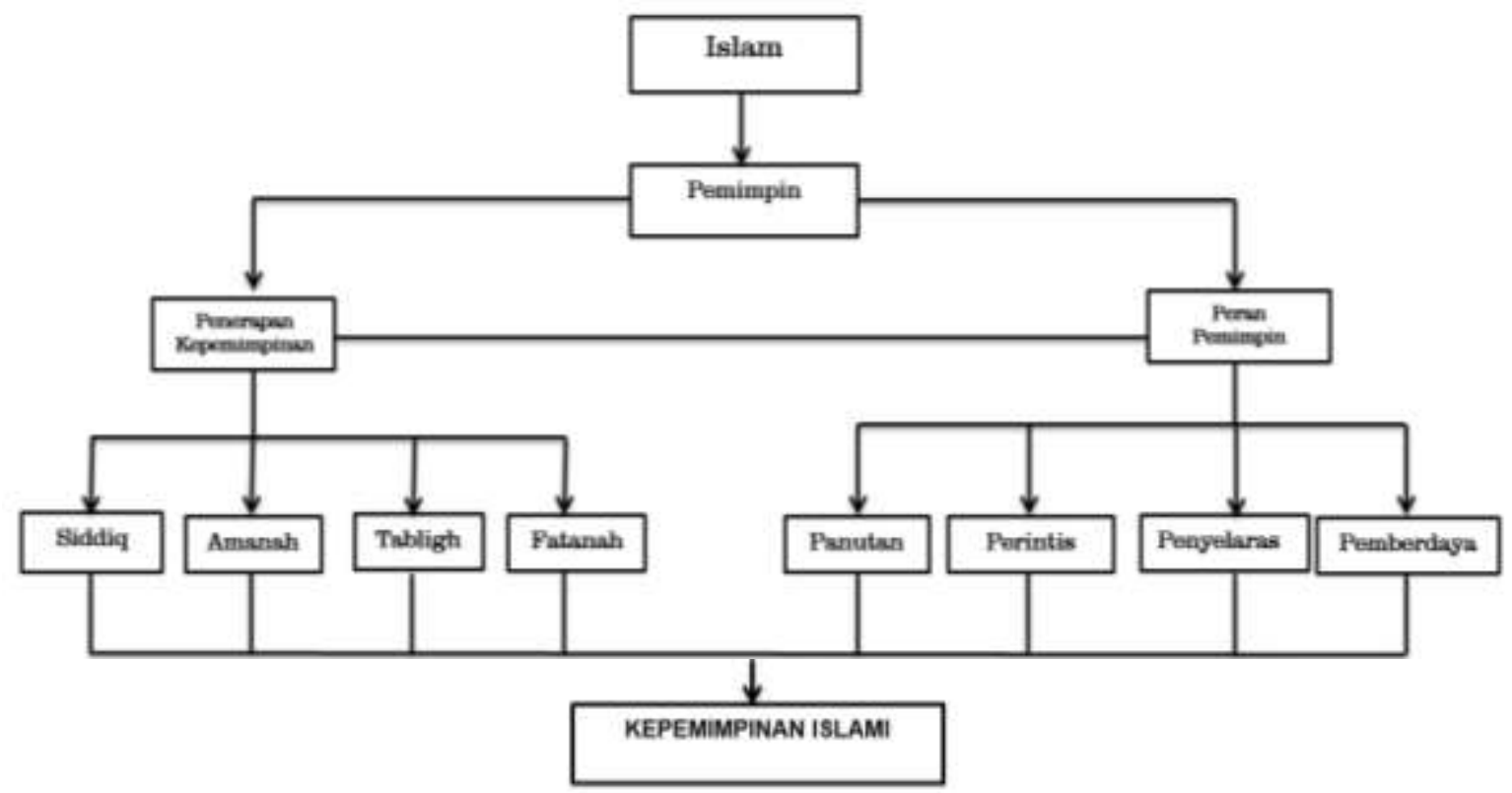

Gambar 1. Kerangka Berpikir Penelitian

Berdasarkan gambar diatas peneliti mencoba menggambarkan kerangka berpikir pada penelitian ini, bahwa seorang pemimpin yang memimpin organisasi yang berbasis Islam tentunya harus menerapkan nilainilai Islam pada setiap pola kepemimpinannya. Dengan kata lain, nilai-nilai yang terkandung di dalam Islam menjadi pijakan pertama bagi seorang pemimpin. Hal tersebut dapat dilihat dari dua sudut pandang yaitu secara penerapan maupun secara peran. Selanjutnya, proses penerapan ini dapat diaplikasikan melalui elemen-elemen dasar dalam Islam seperti siddiq (benar), amanah (dapat dipercaya), fathonah (cerdas), dan tabligh (menyampaikan). Sementara itu, peranan pemimpin dapat disebut benar-benar optimal, apabila bisa bisa menjadi perintis, penyelaras, pemberdaya, dan panutan. Pada gilirannya, semua faktor yang dikatakan di atas akan melahirkan sebuah konsep yang dikenal dengan kepemimpinan Islami. 


\section{HASIL DAN PEMBAHASAN}

Penerapan Kepemimpinan. Sebagai panutan, pimpinan sudah memberikan contoh perilaku yang baik bagi para anggotanya, yaitu tentang pola pikir dan prinsip hidup, berpikir kritis dan mengasah kreativitas, membangun kesadaran, dan kemandirian serta mampu menggerakkan. Sebagai perintis, pimpinan selalu menciptakan inovasi-inovasi baru baik dari kurikulum dan program, serta melakukan pengambilan keputusan dengan jalan musyawarah dan melibatkan semua pihak terkait. Menjadi penyelaras, pimpinan menyelaraskan pola pikir dan pemahaman semua pihak yang terkait, dan juga mampu menyelesaikan permasalahan yang terjadi di internal lembaga dengan jalan musyawarah dan pendekatan kekeluargaan. Sebagai pemberdaya, pimpinan menjadi tempat berkeluh kesah dan mencari solusi permasalahan anggota, mengoptimalkan potensi dan minat para anggotanya baik guru dan santri dengan melengkapi fasilitas dan program pendukung lainnya. Berikut pembahasan secara terperinci.

Pemimpin Sebagai Panutan. Islam adalah agama yang sempurna dan rahmatan lil alamin. Islam mengatur segala sendi dalam kehidupan baik itu secara sosial, ekonomi maupun politik. Tak terkecuali dalam urusan kepemimpinan atau yang sering juga kita sebut leadership. Karena semua itu tak lain karena Islam adalah agama yang sempurna.

Kepemimpinan yang digunakan oleh seorang pemimpin tidak akan lepas dari nilai-nilai yang dianut oleh pemimpin yang juga harus disesuaikan dengan visi misi lembaga yang dipimpinnya. Seperti juga pada lembaga pendidikan Islam Bani Hasyim yang menjadikan Islam sebagai dasar dari semua kegiatan, untuk selanjutnya peneliti membahas bagaimana peran dan penerapan kepemimpinan islami pada lembaga Bani Hasyim.

Kepemimpinan bapak Aji Dedi Mulawarman sebagai direktur pendidikan pada lembaga ini mempunyai daya tarik yang luar biasa bagi para bawahannya, yaitu para kepala sekolah dan para guru-guru di lembaga Bani hasyim. Beliau tidak hanya sekedar mencontohkan prilaku yang baik kepada para kepala sekolah dan para guru, tapi juga memberikan contoh dalam pola pikir dan prinsip hidup bahwa Islam dan ilmu pengetahuan harus selalu menjadi satu, terutama dalam hal pembelajaran. Hal ini terlihat pada pernyataan yang disampaikan oleh beliau yaitu:

"Coba aja hari pertama masuk TK, SD masuk SMP yang" diajarkan mesti 'aku', siapa 'aku'? 'Aku adalah anak dari ini, namaku ini'.. Nggak bisa begitu perkenalan kan mesti begitu, nah mesti dibalik logikanya, apa pelajaran pertamanya? Ya ALLAH! Itu harus didulukan, maka Allah itu harus masuk ke seluruh pelajaran. Islam itu harus masuk ke seluruh pelajaran, gak bisa Islam itu di luar. Islam itu masuk ke seluruh mata pelajaran, agama itu masuk ke seluruh pelajaran, sehingga apa? Terintegrasi! Contoh kasus misalnya, siapa yang menurunkan hujan? Kalau ilmu barat yang menurunkan hujan itu adalah proses penguapan dan 
lain-lain. Proses kimia kan? Kalau Islam gimana ya.. yang menurunkan hujan ini malaikat Mikail, nah itukan pelajaran Aqidah. Ngomong begitu, pelajaran biologi ngomong begini, sehingga anak menjadi sudah sekuler. Yang kedua, split of personality, pecah kepribadiannya. Maka pecah kepribadian itulah yang menjadi titik awal dari korupsi, orang frustasi, orang stress, orang tidak peduli dengan agama, nah itulah diintegrasikan sejak dini. “

Dari pernyataan tersebut terlihat bahwa direktur pendidikan menginginkan nilai nilai Islam dapat diintegrasikan dengan ilmu pengetahuan agar nilai-nilai Islam masuk sejak dini kepada para siswa, agar ketika sudah dewasa para siswa mempunyai prinsip yang kuat dalam menjalani hidup dan tidak mudah terpengaruh untuk melakukan hal-hal yang di luar norma terlebih dilarang oleh Islam. Hal ini juga di dukung oleh pernyatan Bapak Ari sebagai kepala sekolah SMP yaitu:

"Bagaimana menjadi harapan dari pendiri itu kan bagaimana anak-anak kita itu kan menjadi pemimpin yang punya akhlaqul karimah punya sesuatu yang membanggakan untuk bangsa negara dan agama, itu yang utama."

Beliau menjelaskan bahwa apa yang diharapkan oleh pendiri termasuk direktur pendidikan adalah santri-santri Bani Hasyim sebagai generasi penerus bangsa dapat menjadi pemimpin yang mempunyai akhlak karimah dan bisa melakukan sesuatu yang bermanfaat bagi agama, bangsa, dan negara.

Disampaikan juga oleh Ibu Qurruta Ayun selaku kepala SD Bani Hasyim bahwa Bapak Aji Dedi selaku direktur pendidikan selalu memberikan contoh yang baik, selalu merangsang para kepala sekolah dan guru-guru untuk berfikir kritis dan jauh ke depan, kreatif dalam membuat kurikulum dan metode ajar yang mengacu pada visi misi yayasan, sebagaimana yang disampaikan berikut:

“...Wah kalau pak dedi itu ya luar biasa, saya selalu merasa haus dalam arti haus secara intelektual kalau tidak bertemu dengan beliau, apalagi sekarang sudah jarang bertemu. Beliau itu selalu mengajak kita untuk berpikir berbeda dari yang lain, kita disuruh mengkritisi kurikulum yang sudah ada, yang dari diknas itu, pokoknya harus buat yang berbeda, karena untuk mencapai visi misi kita tidak bisa dengan kurikulum model dari diknas itu, gak bisa gak bisa kesampaian."

Dari pernyataan tersebut bisa dilihat bahwa Pak Aji Dedi Mulawarman selaku pimpinan secara tidak langsung menanamkan nilai-nilai kemandirian, nilai kritis dan mampu berkarya. 
Pemimpin Sebagai Perintis. Setelah pemimpin dapat menjadi panutan dan memperoleh kepercayaan dari pengikut, selanjutnya terdapat peran pemimpin sebagai perintis jalan. Fungsi pathfinding ini merupakan peran pemimpin dalam memenuhi kebutuhan organisasinya berkaitan dengan pelaksanaan visi dan misi organisasi (Syafii, 2009). Nilai-nilai Islam harus menjadi dasar dalam proses pengambilan keputusan, yaitu musyawarah. Hal ini dijelaskan oleh bapak Aji selaku Direktur pendidikan sebagai berikut:

"...Pengambilan keputusan manajemen sekolah ya gimana, ya dirapat direktur itu, yang jelas ya demokratis lah dan saya tidak pernah cawe-cawe kalau sudah hasil kesepakatan di rapat ya sudah, mereka bebas, meskipun tetap ada pengawasan yaa.."

Hal ini menggambarkan bahwa pemimpin menghargai setiap keputusan yang sudah dihasilkan oleh musyawarah yang dilakukan oleh pimpinan di setiap sekolah guru dan juga direktur, yang terpenting tidak menyimpang dari visi misi sekolah. Proses pengambilan keputusan yang berkenaan dengan santri atau wali santri itu pasti dilakukan musyawarah dengan melibatkan santri atau wali santri, seperti yang disampaikan oleh bapak Hasyim, wali santri dari siswa SD sebagai berikut:

"Iya mas, biasanya kita dilibatkan untuk musyawarah, misalnya ketika anak-anak mau study tour, kita ya wali santri dipanggil untuk musyawarah, enaknya kemana dan maunya kemana tujuan tournya itu."

Hal ini menunjukkan bahwa pimpinan juga menghargai dan mengajak wali santri untuk ikut terlibat dan punya rasa tanggung jawab atas apa yang sudah direncanakan bersama. Ini juga menggambarkan bahwa nilai-nilai islami sudah dilaksanakan pada proses pengambilan keputusan di Bani Hasyim.

Selanjutnya dalam hal inovasi, berdasarkan hasil pengamatan dan wawancara peneliti, banyak sekali program-program inovasi yang sudah di buat oleh Bani Hasyim, mulai dari membuat kurikulum sendiri yang berbeda dengan diknas, pengintegrasian nilai-nilai islam dengan pegetahuan, pengembangan anak sesuai minat bakat, pembiasaan catur, kreativitas kesemestaan, tahfidz setiap pagi, memakai sandal ketika kesekolah, permainan tradisonal, shodaqoh seribu sehari untuk masjid, proyeksi masa depan, karya ilmiah, ngaji kitab kuning untuk para guru, penilaian dan rapot secara kualitatif, arisan keliling siswa dan banyak lagi inovasi-inovasi yang mengintegrasikan nilai-nilai islami baik untuk siswa dan juga untuk para guru. Karena kurikulum di Bani hasyim linear integratif mulai dari KB-TK, SD, SMP yang mengarah pada pembiasaan, kesadaran dan menggerakkan dengan nilai-nilai Islam.

Pemimpin Sebagai Penyelaras. Pemimpin sebagai penyelaras adalah pemimpin yang mampu mensinergikan bagaimana keseluruhan organisasi 
bekerja. Pemimpin mengetahui segala seluk beluk dalam organisasinya dan karakter pegawai yang memiliki banyak perbedaan di dalamnya. Segala sesuatu yang direncanakan dapat berubah sesuai dengan kehendak Allah SWT karena manusia bisa berencana, namun semua kembali kepada Allah SWT

Secara umum seluruh partisipan sepakat mengemukakan bahwa penerapan nilai-nilai Islam dalam fungsi kepemimpinan sebagai penyelaras adalah menyelaraskan pemikiran dari semua elemen yang ada di Bani Hasyim, mulai dari direktur, para kepala sekolah, guru, santri dan wali santri, semua harus mempunyai tujuan dan pemahan yang sama dengan visi misi yang sudah ada, agar tercipta iklim yang saling mendukung satu sama lain. Berikut dapat dilihat dari pernyataan pak Aji Dedi Mulawarman:

"...jadi guru guru itu tiap semester tak training, saya yang nraining wong saya direkturnya kan, tak training trus bikin kurikulum sendiri buku ajar sendiri, wajib, pokoknya ndak boleh murid murid beli buku ajar itu, wes bikin ajah."

Disampaikan oleh pak Ari juga bahwa harus ada kesadaran bersama, dari kesadaran itu akan muncul kemandirian, dengan kemandirian itulah kita tidak akan selalu bergantung dengan pimpinan, ada atau tidak pimpinan maka kegiatana harus tetap berjalan, tergambar dari kutipan wawancara berikut:

"Yaa itu kan salah satunya, tapi yang paling penting itu kan membentuk kesadaran itu tadi kan yang utama itu, kalo gurunya dilakukan pelatihan tapi ye tetep gak sadar yo tetep ae kan. Nah membangun kesadaran itulah yang sulit karena untuk menuju kesadaran itu perlu artinya pembiasaan, jadi kan kalo gak ada pembiasaan kan gak da ruhnya, adanya keterpaksaan, karena pembiasaan itu yang utama. Ada pembiasaan ada kebiasaan, ada kebiasaan pasti dia mandiri tanpa ada siapapun dia melakukan gitu loh, tapi kalo gak ada kesadaran 'ohh ono Pak Ari baru ngerjakno, onok Pak Edy baru ngerjakno'. Nah itu yang salah. Misalkan Pak Dedi Pak Danang jarang ke sini, tapi karena ada kesadaran lembaga ini harus tetep lanjutkan tidak nunggu kesadaran dan mandirinya dapet."

Kesadaran menjadi hal yang paling utama untuk mencapai kemandirian, jika semua sudah satu visi maka akan mudah untuk mencapai apa yang diinginkan bersama.

Pemimpin Sebagai Pemberdaya. Fungsi pemberdayaan adalah pemimpin yang mampu mengalokasikan fasilitas sumber daya yang diberikan, supaya orgaisasi dapat berjalan dengan lancar dan sesuai dengan kebutuhan. Menurut Covey (2005), pemimpin harus berhasil menjadi panutan, merintis, dan menyelaraskan organisasi terlebih dahulu sebelum dapat 
memberdayakan sumber daya dalam organisasi. Hal ini dikarenakan pemberdayaan merupakan hasil dari ketiga hal tersebut. Sehingga pemimpin harus mampu mejadi tempat bertanya bagi bawahannya.

Enam dari sepuluh informan menyampaikan bahwa pemimpin di Bani Hasyim sudah menerapkan peran sebagai pemberdaya, yaitu dengan selalu menularkan hal yang baik dan mampu menjadi tempat berkeluh kesah, dilihat dari pernyataan yang di sampaikan Bu Qurrota Ayun:

"wah biasanya pak aji itu sering manggil kita, malem-malem suruh ke rumahnya, tauya Cuma suruh denger kegelisahannya, hahaha,,, tapi dari itu kita banyak mendapat pelajaran dan ikut resah juga, ada kehausan intelektual gitu. Dan sering juga kita bertanya kalau ada yang bingung dan kadang curhat juga."

Dari pernyataan tersebut bisa dilihat bahwa antara pimpinan dan anggota di bawahnya harus membangun komunikasi yang baik agar tercipta keharmonisan dalam bekerja. Pernyataan ini di dukung oleh Ibu Muridi seorang wali santri, sebagai berikut:

"ya sering mas, kadang kita curhat juga sama guru, sama

kepala sekolah tentang perkembangan anak di rumah gimana, kan akrab banget mas, gimana ya gak tertutup gitu."

Dari pernyataan tersebut bisa dilihat bahwa pemimpin di Bani Hasyim sangat terbuka sekali kepada para wali santri, apalagi ketika bersangkutan dengan perkembangan anak di rumah.

Penerapan Pemimpin. Nilai yang diterapkan untuk penerapan kepemimpinan Islami sudah ada dalam praktik keseharian pimpinan Bani Hasyim. Nilai siddiq ini nampak bukan hanya benar pada aspek pribadi, tapi juga pada tujuan pendirian organisasi, visi misi, kebijakan, program dan inovasi yang dibuat dengan dilandaskan pada nilai religiusitas, juga dengan menjadi contoh yang baik dengan menjalankan peraturan dengan benar, membangun kesadaran melalui pembiasaan untuk menciptakan kemandirian. Amanah terhadap tugas dan tanggung jawab yang diemban, meski ada pengawasan maupun tidak, dengan kata lain sami'na waato'na, juga menjalankan semua keputusan yang diperoleh dari hasil musyawarah. Nilai tabligh nampak pada cara berkomunikasi dengan menggunakan bahasa yang baik dan sopan, baik dengan sesama pimpinan maupun para anggota dan santri, menciptakan iklim kekeluargaan agar lebih mudah dalam mentransfer nilai-nilai pengetahuan, kebudayaan serta nilai-nilai keaagamaan. Nilai fatonah terlihat dari inovasi-inovasi dan program yang dibuat guna mencapai visi yayasan yaitu mewujudkan manusia yang Ulil Albab.

Siddiq (benar). Siddiq atau benar adalah sifat Rasulullah SAW dalam mencintai adanya kebenaran yang datang dari Allah SWT, maka seluruh 
kegiatan, perilaku, ucapan, emosi, bahkan diamnya Rasulullah SAW merupakan sesuatu yang benar. Siddiq dalam kepemimpinan Rasulullah SAW berarti bahwa, seluruh keputusan, perintah, dan larangannya merupakan sesuatu yang pasti benar, hal ini bermaksud untuk mewujudkan kebenaran dari Allah SWT (Nawawi, 2001). Nilai kejujuran atau kebenaran juga dapat dilihat dari pernyataan pak Ari sebagaimana berikut:

"Nah ini yang punya cita-citanya seperti itu, jadi tidak mikir profite tapi kan bagaimana pak Abbas itu bermanfaat lah bagi ummat."

Dari pernyataan tersebut dapat dilihat bahwa pendiri (Pak Abbas) dan Pak Aji sebagai Direktur Pendidikan mempunyai jiwa perintis yang tetap menjadikan nilai Islam sebagai pedoman, sifat-sifat kebenaran yang diajarkan Rosulullah juga harus masuk pada tujuan awal mendirikan suatu organisasi dan program-program yang dijalankan. Sebagai pimpinan dalam mendirikan yayasan tidak hanya semata-mata tujuan untuk mendapatkan profit, tapi juga bagaimana beliau dalam semasa hidupnya bisa bermanfaat dan sepeninggalnya beliau bisa meninggalkan sesuatu yang pahalanya akan tetap mengalir, karena yang ditinggalkan dapat bermanfaat bagi banyak orang atau dalam istilah lain disebut amal jariyah.

Para pemimpin di Bani Hasyim sudah memberikan contoh yang baik kepada seluruh civitas yang ada di Bani Hasyim mulai dari pada guru, karyawan, siswa bahkan sampai kepada wali siswa. Menjadi panutan dalam hal ini bukan dengan memerintahkan berlaku baik pada para anggota, namun dengan terlebih dahulu mencontohkan perilaku yang baik yang dimulai dari diri sendiri. Ketika para anggota melihat pemimpinnya sudah berlaku baik maka akan timbul kesadaran dari dalam diri anggota untuk meniru dan melakukan hal yang baik juga. Hal ini sesuai dengan konsep Islam bahwa berdakwah tidak dengan paksaan, melainnkan dengan rahmatan lil'alamin. Contoh perilaku yang baik ini bisa dalam bentuk apa saja, dimulai dari hal yang sederhana seperti menjaga kebersihan, karena menjaga kebersihan merupakan sebagian dari iman. Hal ini dapat dilihat dari pernyataan pak Edy salah seorang guru di SMP Bani Hasyim:

"Pak Ari ini pokoknya orangnya langsung praktek, langsung" kerja gituloh, jadi anak misalkan ini tentang kebersihan harus ini ini... ndak usah, jadi pak ari itu langsung di ajak bersih-bersih, sosial amaliyah langsung diajak dan anak-anak akan meniru."

Dari beberapa pernyataan tersebut dapat disimpulkan bahwa kepemimpinan di Bani Hasyim sudah menerapkan sifat kepemimpinan islami yaitu siddiq (benar). Pemimpin bukan hanya benar pada aspek pribadinya, namun juga nampak pada orientasi pendirian organisasi, visi misi, pada setiap kebijakan, program dan inovasi-inovasi yang dibuat, yang tentunya harus dilandaskan pada nilai religiusitas. Penerapan nilai Siddiq juga adalah bagaimana menjadi panutan atau contoh yang baik bagi anggotanya, 


\section{Kepemimpinan islami dalam ....}

Asmuni, I.E.

memberikan kesadaran melalui praktek langsung, melakukan pembiasaanpembiasaan pada programnya yang kemudian akan dicontoh dan akan menimbulkan kemandirian para anggotanya, hal ini sesuai dengan konsepsi Islam bahwa berdakwah harus rahmatan lil'alamin, bukan dengan paksan.

Amanah (dipercaya). Amanah merupakan sifat dapat dipercaya atau mampu menjaga kepercayaan orang lain yang diberikan kepada kita sebagai bentuk tanggung jawab, dan kita berkewajiban menyelesaikan dan menjalankan tanggung jawab tersebut, ada atau tidak ada, diawasi atau tidak oleh orang yang memberikan kepercayaan tersebut. Amanah merupakan tanggung jawab yang diberikan Allah SWT kepada yang dipilihNya. Seseorang yang mendapatkan amanah dilarang untuk khianat atau ingkar terhadap tanggung jawabnya. Hal ini sesuai dengan firman Allah SWT dalam Surat Al Anfal ayat 27 yang memiliki arti sebagai berikut

"Hai orang' yang beriman, janganlah kamu mengkhianati Allah SWT dan rasul dan janganlah kamu mengkianati amanah yang dipercayakan kepada kamu, sedang kamu mengetahuinya" (QS. Al Anfal 27)

Tentang amanah dan tanggung jawab, pak Ari salah satu informan menyampaikan hal berikut:

"Karena kepentingan yang sama inilah ketiga pendiri ini kita Sami'na Wa Ato'na istilahnya kan gitu, tapi sami'na wa 'ato'na itu dalam hal kebaikan, bukan sesuatu yang berbeda jadi ketika Pak Dedi bilang A, Pak Danang bilang A, Pak Abbas ya bilang $A$, ya pimpinan juga harus bilang $A$, gak bisa kita bilang $B$, karena sami'na wa atokna tadi hilang. Kenapa? Karena akhirnya kalo kita bilang $B$ akhirnya terjadi gesekan, jelek."

Dari pernyataan itu digambarkan bahwa para pimpinan kepala sekolah memegang prinsip Sami'na Wa Ato'na, patuh dan tunduk dalam hal kebaikan dengan apa yang diinginkan oleh pendiri yayasan, hal itu merupakan gambaran dari sifat amanah. Disampaikan juga oleh informan lain $\mathrm{Bu}$ Qurrata Ayun selaku kepala SD bahwa, selalu ada rapat evaluasi terkait program yang sudah dilakukan, digambarkan dari kutipan wawancara berikut:

"Kita selalu ada rapat evaluasi dengan para pimpinan dan guru, apakah kurikulum yang sudah di lakukan sesuai dengan yang diharapkan atau tidak, apakah perlu ada perubahan atau tidak dan setiap guru wajib mengevaluasi program-program dari kurikulum itu, nanti dimusyawarahkan lagi." 
Hal ini dilakukan untuk melihat kesesuaian antara tujuan awal dan praktek yang terjadi dilapangan, sebagai bentuk amanah dari visi misi dan kurikulum.

Tabligh (menyampaikan). Berdasar pertanyaan yang diajukan peneliti kepada bapak Edy selaku guru SMP terkait dengan komunikasi pemimpin dengan para anggotanya sebagai berikut:

"Pak Ari itu akrab dengan semua guru, orangnya nyantai luwes, ya gitu, orangnya sandalan, pakai kemeja pakai sepeda, sering bercanda dengan kita, ya meskipun tetap dalam koridornya ya. Pak Ari juga sering mengingatkan kita tentang program, menanyakan bagaimana perkembangannya. Artinya komunikasinya enaklah, jadi kita lebih terbuka."

Dari pernyataan tersebut bisa digambarkan bahwa pak Ari sebagai pemimpin mempunyai cara tersendiri untuk dekat dengan para guru, hal itu akan memudahkan transfer nilai kepada para anggota atau guru. Para guru juga merasakan nyaman berkomunikasi dengan pimpinannya.

Salah seorang murid di SMP Bani Hasyim yang bernama wafi ketika ditanya oleh informan tentang bagaimana komunikasi guru dan pimpinan di sekolah menyampaikan sebagai berikut:

"Iya mas, anak-anak di sini itu akrab dengan guru-guru, seperti sahabat, sering ngobrol bareng bahkan kadang makan-makan bareng. Beliau-beliau itu tidak mendoktrin, tapi mengajak belajar bersama, mereka mengarahkan kita kepada minat bakat kita, jadi meskipun kita gak masuk kelas tapi main badminton atau olahraga yang lain itu gak papa, yang penting bener-bener."

Dari pernyataan tersebut bisa dilihat bahwa memang para guru dan pimpinan di sekolah Bani Hasyim memang memiliki kedekatan dengan para siswa. Dengan kedekatan itu para guru akan lebih mudah untuk mentransfer ilmu dan nilai-nilai keislaman, lebih mengarahkan kepada minat bakat para siswa, karena para guru dan pimpinan memegang prinsip bahwa setiap anak mempunyai kemampuan yang berbeda-beda. Hal ini juga dapat dilihat dari pernyataan pak Ari sebagai berikut:

"Setiap anak itu kan punya kemampuan yang berbeda, tidak semua bisa matematika, IPA, makanya kurikulum kita berbasis program dan pembiasaan, kita buatkan lab catur, kita sediakan lapangan sepak bola, dan fasilitas lain yang menunjang kemampuan mereka."

Pada pernyataan tersebut dapa dilihat bahwa kepala sekolah di sekolah ini memang menekankan pada minat bakat para siswa, maka dari itu pihak sekolah berupaya yang terbaik untuk melengkapi semua fasilitas dan sarana untuk mendukung kreatifitas para siswa. 
Fatonah (cerdas). Kecerdasan beliau juga dipergunakan dalam menyelesaikan masalah ketika tidak mendapatkan wahyu Allah SWT. Rasulullah SAW sebagai pemimpin akan mencari pemecahan masalah yang paling bijaksana dan tidak menyimpang dari ajaran agama Islam. Sudah sepatutnya kita sebagai ummatnya untuk meniru dan mengaplikasikannya dalam setiap bidang kehidupan kita, terutama dalam praktik kepemimpinan. Sebagaimana yang disampaikan oleh ibu Novi salah seorang informan menyampaikan terkait kecerdasan pemimpin dalam menyelesaikan masalah sebagai berikut:

"Bu Emi itu fokusnya emang di TK. Kalau masalah kemampuan yang berbau ke-TK-an itu istilah jawanya ngelonthok lah. Dia itu tau semua mulai dari anak ini kondisinya seperti ini, oh ini caranya harus dari orang tuanya, orang tuanya seperti apa ini, salah asuh atau apa. Atau misalnya, oh anaknya model seperti ini, model pembelajarannya seperti ini, itu Bu Emi paham banget itu. Kalo misalnya ada emm,,,guru juga seperti itu, misalnya saya ngajar,saya ngajarnya itu ke anak-anak,ke anaknya itu gk begitu emm,,, apa namanya kurang, paham Bu Emi. Misalnya ada guru baru 'Iku koyokane kok gak iso iki gitu lho, kayaknya ilmu ke TK-annya belum gitu lho, jadi jangan taruh jadi wali kelas dulu', paham beliau itu."

Dari pernyataan tersebut dapat dilihat bahwa bu Emy selaku pemimpin sekolah di KB-TK mempunyai pengetahuan yang mendalam tentang hal yang berbau ke TK-an, bahkan sampai ada istilah ngelothok, hal ini menunjukkan bahwa pengetahuannya sudah teruji dan banyak bukti secara mendalam dari berbagai pengalaman dalam menyelesaiakan permasalahan yang terjadi.

Disampaikan oleh Ibu Novi, informan guru KB-TK atas pertanyaan peneliti tentang kedekatan dengan pemimpin dan respon pemimpin ketika dimintai pendapat sebagai berikut:

'Ya akrab, kadang' ya guyon, namanya orang' kan wataknya kadang kalau misalnya lagi apa, lagi lihat sampah itu kita disindir untuk ngebersihkan itu biasa, tapi kalau kadung guyon yo guyon gitu, kadang ya kita curhat dan beliau meresponnya dan ngasih solusi. Kadang juga ngajak jalan senengane kan emang ngajak jalan-jalan entah itu sowan ke Pasuruan, ziarah-ziarah ke wali-wali."

Dari pernyataan tersebut dapat dilihat bahwa Ibu Emy sebagai pemimpin merupakan orang yang cerdas, karena mampu memberikan solusi kepada para guru yang bertanya atas permasalahan yang dihadapinya. Pemimpin yang cerdas juga dapat dilihat dari inovasi-inovasi program yang dibuat. Berikut pernyataan dari ibu Novi terkait inovasi-inovasi dari pimpinan:

"He em, tahfidz itu mengalahkan semua. Kayak misalnya ada olahraga renang, nah tahfidz dulu, jangan karena renang 
takutnya ngga mencukupi waktunya tahfidznya ditiadakan ngga seperti itu, apapun apa misalnya emm ya kayak lomba ada lomba apa pokoknya kegiatan pentas-pentas itu pasti tahfidz dinomorsatukan. Kalau setelah tahfidz bebas mau kegiatan apa."

Dari pernyataan di atas bisa dilihat bahwa upaya pemimpin untuk menanamkan nilai religiusitas kepada para siswa diwujudkan dalam program tahfidz. Program tahfidz ini adalah program pembuka seluruh kegiatan di sekolah, semua kegiatan belajar mengajar harus diawali dengan mengaji, hal ini adalah upaya pembiasaan yang dilakukan untuk menciptakan kesadaran ilahiyah para siswa-siswi.

Dari beberapa uraian diatas peneliti beranggapan bahwa kepemimpinan di Bani Hasyim sudah menerapkan nilai Fatonah. Kecerdasan dan mencerdaskan ini nampak pada pemimpin yang mampu menjadi tempat bertanya bagi para anggotanya, mampu menyelesaikan persoalan yang terjadi dengan sikap komunikatif, mamiliki pandangan visioner akan masa depan, serta inovasi-inovasi program yang kreatif sebagai media mentrasfer nilai-nilai islami dan kebudayaan serta mampu mensinergikan dengan ilmu pengetahuan dan perkembangan zaman, sehingga mampu mewujudkan visi yayasan yaitu terwujudnya manusia yang Ulil Albab.

\section{SIMPULAN}

Pemimpin dilembaga Bani Hasyim sudah mampu menjalankan perannya sebagai panutan, perintis, penyelaras dan pemberdaya. Selain itu juga, kepemimpinan di Bani Hasyim sudah menerapkan nilai-nilai islami, yaitu siddiq (benar), amanah (dipercaya), tabligh (menyampaikan) dan fatonah (cerdas). Berdasarkan peneltian ini, peneliti menyarankan agar pimpinan lebih sering komunikasi dan silaturrahmi dengan para anggotanya, terutama direktur pendidikan agar mereka termotivasi dengan wawasan dan pengetahuan yang baru. Pimpinan juga harus lebih sering mengadakan pengakaraban dengan media jalan-jalan atau kumpul-kumpul agar dapat dengan mudah mentransfer nilai atau menyelesaikan permasalahan. Keistiqomahan dalam mendidik dengan nilai Islam harus tetap dijaga, kreativitas harus terus dikembangkan dan program-program baru harus terus selalu dibuat, dan juga media publikasi harus dikembangkan, contohnya hasil karya-karya siswa-siswa bisa dipublikasikan melalui web dan media sosial lain, agar bisa menggerakkan dan menginspirasi orang-orang luar dan bisa lebih mudah ketika orang ingin mencari informasi tentang Bani Hasyim. 


\section{Kepemimpinan islami dalam .... Asmuni, I.E.}

\section{DAFTAR RUJUKAN}

Adiba, E. M. (2018). Kepemimpinan Islami, Kepuasan Kerja, Komitmen Kerja, Dan Loyalitas Kerja Karyawan Bank Syariah Mandiri Di Sidoarjo. AlUqud: Journal of Islamic Economics, 2(1), 60-80.

Covey, S. (2005). The 8th Habit. Jakarta: Gramedia Pustaka Utama.

Departemen Agama RI. (2015). Al Quran Terjemah Al Muhaimin. Jakarta: Al Huda

Kamayanti Ari. (2016). Metodologi Konstruktif Riset Akuntansi membumikan Religiusitas. Jakarta: Yayasan Rumah Peneleh.

Nawawi, H. (2001). Kepemimpinan Menurut Islam (2nd ed.). Yogyakarta: Gadjah Mada University Press

Syafii, A. (2009). Muhammad SAW: The Super Leader Super Manager. Jakarta Selatan: Tazkia Publishing and ProLM Centre.

Subhan, M. (2013). Kepemimpinan Islami dalam Peningkatan Mutu Lembaga Pendidikan Islam. Tadrîs, 8(1), 125-140.

Husna, F. (2017). Kepemimpinan Islami dalam Meningkatkan Mutu Lembaga Pendidikan Islam. Misykat, 02(02), 131-154.

Ikhwan, A. (2018). Sistem Kepemimpinan Islami: Instrumen Inti Pengambil Keputusan pada Lembaga Pendidikan Islam, 3(2), 111-154.

Muzammil, M. (2017). Konseptualisasi Kepemimpinan Islami dalam Pengembangan Pendidikan Islam. At-Turās, IV(2), 256-278.

Shalihah, M. (2015). Peran Kepemimpinan Islami dalam Peningkatan Manajemen UsahaPerusahaan. Tahkim, XI(2), 115-129. 